\title{
Hidden hunger in Benin: the scope and prospectus.
}

\author{
Lincoln J Fry* \\ Sociology Research Unit, Athens Institute for Education and Research (ATINER), Athens, Greece
}

\begin{abstract}
Hunger is a worldwide problem, and Africa is the continent with the world's highest percentage of hungry persons; Benin is one of Africa's poorest and hungriest countries, and this paper addresses those issues and then identifies the factors that predict hunger in that country. Benin has a substantial rural population, slightly over half of the sample used in this study resides in rural areas, and those respondents will receive some attention in this paper, especially because the paper looks closely at literature's suggestion that African farmers may be hungrier than the rest of the population, and also that gender may be a factor. This study is based on a national probability sample of 1,200 Benin respondents included in Round 6 of the Afrobarometer survey conducted in 2014. The search is for policy related factors that might help alleviate Benin's hunger problem. To preview the findings, this study did not find any light at the end of the tunnel regarding hunger for Benin.The findings do provide information about the extent of hidden hunger in Benin. The results highlight the role of poverty as the root cause of hunger in Benin. The study found support for the notion that farmers are hungrier than other respondents, but gender and urban -rural differences disappeared in the analysis. The surpring findings were that respondent's perceptions that the government was not ensuring that people have enough to eat and not handling improvement of the living standards of the poor were highly, as well as age, significant predictors of hunger in Benin.
\end{abstract}

Keywords: Benin, Hunger, Rural, Agriculture, Farmers

Accepted on January 09, 2018

\section{Introduction}

Benin is a country in West Africa, bordered by Burkino Faso, Niger, Nigeria, Togo as well as the Atlantic Ocean. Descibed as increasingly stable, Benin still faces many challenges such as extreme corruption and a low adult literacy rate. Hunger is another major problem and this paper assesses the extent of self-reported hunger among 1,200 Benin respondents and then searches for the factors that predict hunger in that country. Even though Benin has been somewhat neglected, the literature devoted to what is commonly called food insecurity will be reviewed. Some of the issues raised in the African food insecurities literature will be addressed and are questions central to this paper's analysis. These include whether rural residents, especially agricultural workers, are hungrier than other Benin respondents, as well as whether there are gender differences in the degree of hunger. The discussion section will attempt to answer the question as to whether this paper has any implications or adds any knowledge about hidden hunger in Benin.

\section{Hunger in the World and Africa}

According to the WHES (World Hunger Education Service) World Hunger and Poverty Facts and Statistics Report [1] hunger has three meanings. Two of those meanings deal with craving or desire for food. The third meaning refers to the want or scarcity of food in a country, and it is in this sense that this paper addresses hunger. There are two classifications of hungry person that are of interest here. The broadest classification includes those who suffer from what is known as "hidden hunger". Since this paper utilizes a self report measure to assess hunger, the results reported in this paper may be seen to more closely reflect hidden hunger. These are an estimated two billion persons that are affected by a chronic deficiency of essential vitamins and minerals. Among this population the signs of malnutrition and hunger are less visible, but it has negative and long term consequences, often for long term health, productivity and cognitive development [2]. The second classification includes those who demonstrate clear cut hunger; in the latest UN Food and Agriculture Organization Report [3] the estimate was that 925 million people were hungry worldwide, and that 239 million people in sub-Saharan Africa were hungry or undernourished. This made Africa the continent with the second largest number of hungry people, following Asia and the Pacific with 578 million. Due to the difference in population sizes, Sub-Saharan Africa actually had the largest proportion of hungry/undernourished people, estimated at 30 percent of the population compared to 16 percent for Asia and the Pacific.

\section{Food insecurity in Sub-Saharan Africa}

As Clover [4] has suggested, despite the fact that the right to food is one of the most consistently acclaimed assertions in international human rights law, no other human right has been so frequently and spectacularly violated. Her discussion of food insecurity in Sub-Saharan Africa leads to the conclusion that hunger is a multi-faceted issue in Africa, and that just growing more food will not eradicate the problem. Agriculture is important and Clover points out that Africa has gone from being a key agricultural commodity exporter into being a net importer; the African continent now receives the most food aid. Perhaps the most important point Clover made was to suggest hunger will not be eradicated by just throwing money at the problem. 
Hunger is a political creation which must be ended by political means, a theme which will be mentioned below and revisited in the Discussion section.

\section{Identified hunger in Benin}

Malnutrition is the $8^{8 \mathrm{~h}}$ leading cause of death in Benin, and the 10th leading cause of total deaths in the country; the country ranks 23rd in the world in this category [5]. According to the World Food Program [6]. Benin relies on agriculture as the basis of its food security as well as economic development. Agricultural development is hindered by factors such as lack of modern farming technology, poor soil, high food prices and inadequate storage, preservation and food processing. The country is also highly vulnerable to natural disasters, like flooding and drought, which contribute further to nutritional instability. According to the World Food program, in Benin ,16 percent of children under 5 suffer from acute malnutrition and 45 percent of that same age group are described as chronically malnourished.

\section{Hunger related factors}

According to Sanchez and Swaminathan [7] roughly half, 50\%, of the hungry worldwide are found in small holder farming households. and most likely three-quarters of the hungry in sub-saharan Africa. This paper will look at farmers, in order to determine if they are in fact hungrier than other Benin respondents. There are several issues that emerge from the rural hunger literature that will affect all farmers. The first is climate change Shisanya and Mafongoya [8] who suggested that smallholder subsistence farmers will face severe negative impacts from climate change, with their household food security being seriously affected. This paper also addresse the way gender affects hunger in Benin, especially female farmers. As Sanchez, and Swaminathan [7] have indicated, the division of labor is becoming blurred. Many men have left the land to work in the towns or neighboring countries. Also, HIV related diseases and deaths have had a major effect on the agricultural labor force As a result, women sometimes comprise up to $80 \%$ of the adult rural population and made to take on jobs that were traditionally done by men.

\section{The study: the research question}

The picture of Benin presented above is grim. It is described an impoverished country with limited resources that cannot overcome its hunger problem in the near future. Against that backdrop, this study looks at the scope of hunger in Benin and attempts to identify the factors that are related to hunger in present day Benin. As the title of this paper suggests, the search will be to determine whether there are any rays of hope for the hunger problem in Benin, or is hunger destined to be perpetual.

\section{Methods}

\section{The data}

This study's Data Source is the Afrobarometer project, As recently described by Fry [9], it is a collaborative research effort formed in 1999 when three independent research projects merged, there were three core partners involved, Michigan State University, the Institute for Democracy in South Africa and the
Center for Democratic Development. The Project's objectives are as follows; 1) to produce scientifically reliable data on public opinion in sub-Saharan Africa; 2) to strengthen institutional capacity for survey research in Africa; and 3) to broadly disseminate and apply survey results. In 2000, Afrobarometer joined other regional barometers to form the Global Barometer Network; the following year, Afrobarometer completed the Round 1 survey. The project started with 12 countries in Round 1, and by 2016 when Round 6 was completed, it included 36 African countries. The project uses a standardized questionnaire, with new questions or country specific questions added by round.

The individual country is the unit of analysis and sampling goal is to create national probability samples which represent cross sections of adult citizens, 18 years and older, for each country. Sampling sizes are set at either 1, 200 or 2,400 respondents, depending upon the country's population size. The sampling procedures used in all of the Afrobarometer surveys are explained in detail in Bratton, Mattes and Gyimah-Boadi [10].

\section{The dependent variable: Hunger}

The study's questionnaire included what is called The Lived Poverty Index used in the Afrobarometer studies which was adopted from Mattes [11]. One of the five questions in the Index asked "over the past year, how often, if ever, have you or anyone in your family gone without enough food to eat". Fixed responses to this question were: never, just once or twice, several times, many times, always. These responses were coded as follows Never $=1$, just once or twice $=2$ and many times and always $=3$. These categories provide the basis for the ordered logistical analysis presented in the Results section.

\section{The independent variables}

The questionnaire did not ask respondents to report their income in the Afrobarometer survey. As Bratton [12] indicated, this is because many citizens in poor countries operate in informal markets where cash transactions, including income, are unrecorded and difficult to measure. Instead, this research used what is called an Asset-based Wealth Index, a summed index created from four questions that ask about household assets. The survey asked respondents: "Which of these things do you personally own: A radio? A television? A motor vehicle, car or motorcycle?, a cell phone?" Responses to these questions were coded as binary. Either $(0=$ don't own; $1=$ own $)$, and used to create a summed index for this study.

Other control variables are listed in Table 1 and were measured by a single item, like age, and others were collapsed into fewer categories. Race was not included in Table 1 because over 99 percent of the respondents were classified as Black Africans. Education was reduced to five categories by combining no school, informal only and completion some primary. Religion was reduced to three categories, Chrisiams, Muslims and others. Respondents were asked a series of work related questions, like their employment status, and to identify their occupations Respondents were asked hypothetical questions, like their first priority for additional investment if the country could increase spending. Fixed responses were provided, which included education, infrastructure, security, healthcare, agriculture and 
Table 1._Social and demographic characteristics of the Benin sample $(N=1,200)$.

\begin{tabular}{|c|c|}
\hline Variable & $\mathbf{N}(\%)$ \\
\hline \multicolumn{2}{|l|}{ Gender } \\
\hline Male & $600(50)$ \\
\hline Female & $600(50)$ \\
\hline \multicolumn{2}{|l|}{ Education } \\
\hline No formal/informal schooling & $486(41)$ \\
\hline Some / Primary school completed & $256(21)$ \\
\hline Some/completed high school & $370(31)$ \\
\hline postsecondary/college /graduation & $84(7)$ \\
\hline \multicolumn{2}{|l|}{ Religion } \\
\hline Christian & $704(60)$ \\
\hline Muslim & $317(27)$ \\
\hline Other & $151(13)$ \\
\hline \multicolumn{2}{|l|}{ Employment } \\
\hline Unemployed & $975(81)$ \\
\hline Employed part time & $43(4)$ \\
\hline Employed full time & $182(15)$ \\
\hline \multicolumn{2}{|l|}{ Residence } \\
\hline Urban & $584(49)$ \\
\hline Rural & $616(51)$ \\
\hline \multicolumn{2}{|l|}{ Age } \\
\hline 18 through 29 & $509(43)$ \\
\hline 30 through 49 & $482(44)$ \\
\hline 50 and over & $208(17)$ \\
\hline \multicolumn{2}{|l|}{ Occupation } \\
\hline Agriculture & $328(27)$ \\
\hline Retail Shop & $285(24)$ \\
\hline None/ student/ housewife/ & $272(23)$ \\
\hline Trader/hawker/vendor & $260(17)$ \\
\hline Unskilled 'skilled labor & $55(5)$ \\
\hline \multicolumn{2}{|l|}{ Asset-based Wealth } \\
\hline None of these & $281(23)$ \\
\hline Radio & $345(29)$ \\
\hline Radio and TV & $331(28)$ \\
\hline Radio, TV and motor vehicle (car or motorcycle) & $241(20)$ \\
\hline
\end{tabular}

development, energy supply or none of the above. The responses to these questions are also listed in Table 1.

Table 1 shows that Afrobarometer met its sampling objective with equal numbers of males and females , 600 each. This Benin sample was relatively young, with 87 percent under the age of 50 . Forty five percent of the respondents have some attendance or have completed primary school, while 38 percent have not attended school or have received informal education only. Thirteen percent attended some or completed high school and 4 percent of the sample have post-secondary education. Only 15 percent of the sample was employed full time rand 81 percent were unemployed. The sample was about evenly split between urban and rural rural, with 51 percent rural. About one quarter, 27 percent, listed their occupations as in agriculture, farming, forestry or fishing. In terms of the assets they owned, 29 percent indicated they only owned a radio, while 23 percent indicated they did not own any of the assets on the list. Twenty percent of the sample owned a radio, TV and a vehicle.

\section{Results}

The next task in the analysis was to identify the respondents self-reported level of hunger and perceptions of problems the government should address or where the government should direct funds if money was available. The responses to those items appear in Table 2.

Table 2 reveals that 71 percent of this Benin sample reported some degree of hunger, with 23 percent indicating they are always hungry. Eighty-two percent indicated the government was doing badly ensuring that citizens had enough to eat. In terms of improving living standards for the poor, 72 percent of the Benin respondents responded that the government was doing badly. Education was the number one area where respondents would invest more funding, if it was available, followed by infrastructure and health care. Agricultural development was fourth, chosen by 15 percent of the respondents.

The next task in the analysis was to cross-tabulate the study's independent variables by hunger. These results appear in Table 3.

Table 3 shows that almost all of the variables included in Table 3 were statistically significant, with gender being the only exception Most variables included in Table 3 were highly significant, at 0.000 . The final task in the analysis was to conduct an ordered logistical regression analysis variables in order to determine which variables predicted hunger in Benin. An ordered logistical model was appropriate because the study had a categorical dependent variable. The statistical program used for all of the analysis presented in this paper was Stata, and Long and Freese [13] discuss the use of regression models for categorical dependent variables when using Stata. The results of this study's ordered logistical analysis appear in Table 4.

Table 4 shows that seven variables reached significance in the regression equation. In order of their strength these were whether respondents thought the government was ensuring that people had enough to eat, respondent 's self reported meeting of their basic needs, the extent of their personal assets, the

Table 2. Self-reported hunger, lack of access to basic necessities (food), and perceptions of governmental priorities and possible investment $(N=1,200)$.

\begin{tabular}{|l|c|}
\hline Variable & N (\%) \\
\hline Hunger & $348(29)$ \\
\hline Never & $581(48)$ \\
\hline Sometimes & $271(23)$ \\
\hline Always & $184(18)$ \\
\hline Go Without Basic necessities (food) & $469(45)$ \\
\hline About once or two or three months & $391(37)$ \\
\hline Two or three times a month or once a week & \\
\hline Several times a week or everyday & $971(82)$ \\
\hline Government ensuring everyone has enough to eat & $216(18)$ \\
\hline Badly & $865(72)$ \\
\hline Well & $333(28)$ \\
\hline Government handling improving living standards for the poor \\
\hline Badly & $395(33)$ \\
\hline Well & $271(23)$ \\
\hline Votes for Top Priority for additional government investment & \\
\hline Education & $219(18)$ \\
\hline Infrastructure & $178(15)$ \\
\hline Healthcare & $89(7)$ \\
\hline Agricultural Development & $37(3)$ \\
\hline Energy Supply & \\
\hline Security & \\
\hline
\end{tabular}


Table 3. Cross-tabulation Hunger and Selected Independent Variables $(N=1,200)$.

\begin{tabular}{|c|c|c|c|c|c|}
\hline \multicolumn{5}{|c|}{ Hunger Level } & \multirow[b]{2}{*}{$\underline{\mathbf{P}}$} \\
\hline & $\underline{\text { None }}$ & $\underline{\text { Some }}$ & A lot & $\underline{\text { Total }}$ & \\
\hline Variable & $\mathrm{N}(\%)$ & $\mathbf{N}(\%)$ & $\mathbf{N}(\%)$ & & \\
\hline \multicolumn{6}{|c|}{ Gender } \\
\hline Male & $275(46)$ & $20835)$ & $117(20)$ & 600 & .21 \\
\hline Female & $259(43)$ & $237(40)$ & $104(17)$ & 600 & \\
\hline \multicolumn{6}{|c|}{ Age } \\
\hline 18 through 29 & $251(49)$ & $192(38)$ & $66(13)$ & 509 & .000 \\
\hline 30 thru 49 & $203(42)$ & $181(38)$ & $98(20)$ & 482 & \\
\hline 50 and over & $79(38)$ & $72(35)$ & $57(27)$ & 208 & \\
\hline \multicolumn{6}{|c|}{ Education } \\
\hline No formal/informal only & $203(42)$ & $164(34)$ & $119(24)$ & 486 & .000 \\
\hline Some / Primary school completed & $90(35)$ & $115(45)$ & $51(20)$ & 256 & \\
\hline Some/completed high school & $192(52)$ & $138(37)$ & $40(11)$ & 370 & \\
\hline Post-secondary/college/graduation & $46(55)$ & $27(32)$ & $11(13)$ & 84 & \\
\hline \multicolumn{6}{|c|}{ Religion } \\
\hline Christian & $248(35)$ & $311(44)$ & $145(21)$ & 704 & .000 \\
\hline Muslim & $235(74)$ & $69(224)$ & $13(4)$ & 317 & \\
\hline Other & $38 \quad(25)$ & $58(38)$ & $55(36)$ & 151 & \\
\hline \multicolumn{6}{|c|}{ Employment } \\
\hline Unemployed & $288(28)$ & $504(49)$ & $246(24)$ & 1,038 & .04 \\
\hline Employed part time & $17(45)$ & $15(39)$ & $6(16)$ & 38 & \\
\hline Employed full time & $43(35)$ & $62(50)$ & $19(15)$ & 124 & \\
\hline \multicolumn{6}{|c|}{ Residence } \\
\hline Urban & $83(49)$ & $61(36)$ & $24(14)$ & 168 & .000 \\
\hline Rural & $265(26)$ & $520(50)$ & $247(24)$ & 1,032 & \\
\hline \multicolumn{6}{|c|}{ Agricultural worker as an occupation } \\
\hline Yes & $191(23)$ & $191(23)$ & $230(28)$ & 518 & .000 \\
\hline No & $145(41)$ & $175(49)$ & $36(10)$ & 356 & \\
\hline \multicolumn{6}{|c|}{ Asset-based Wealth } \\
\hline None of these & $87(21)$ & $190(47)$ & $130(32)$ & 407 & \\
\hline Radio & $124(27)$ & $229(50)$ & $105(23)$ & 458 & \\
\hline Radio and TV & $71(29)$ & $141(59)$ & $29(12)$ & 241 & \\
\hline Radio, TV and motor vehicle & $66(71)$ & $20(22)$ & $7(9)$ & 93 & \\
\hline \multicolumn{6}{|c|}{ Government ensuring everyone has enough to eat } \\
\hline Badly & $282(29)$ & $475(49)$ & $214(22)$ & 971 & .000 \\
\hline Good & $64(30)$ & $99(46)$ & $53(24)$ & 216 & \\
\hline \multicolumn{6}{|c|}{ Government handling improving living standards for the poor } \\
\hline Badly & $335(39)$ & $335(39)$ & 195(23) & 865 & .000 \\
\hline Good & $198(59)$ & 109(33) & $26(8)$ & 333 & \\
\hline \multicolumn{6}{|c|}{ Go Without Basic necessities } \\
\hline About once, two or three months & $92(50)$ & $72(39)$ & $20(11)$ & 184 & .000 \\
\hline Two/three a month/once a week & $202(43)$ & $192(41)$ & $75(16)$ & 469 & \\
\hline Several times a week or Everyday & $94(24)$ & $171(44)$ & $12632)$ & 391 & \\
\hline
\end{tabular}

governments effort to improve the living standards of the poor, age, religion and being an agricultural worker Perhaps what is most interesting are those variables that were expected to be significant and were not. These include gender and the ruralurban dimension, which the literature suggested were both significant predictors of hunger. Perhaps this can be explained by the significance of agriculture as an occupation. These issues will be included in the Discussion below.

\section{Discussion}

At first glance the results of this study suggests it suffers from an abundance of significant results. This is not true in that these results should have been expected and can be interpreted. It must be remembered that the study's dependent variable, hunger, was measured by a single item included in the Afrobameter poverty index [14]. Whether respondents are able to meet their basic needs is central to the items included in the Poverty Index, so the fact that the basic needs item was so highly significant was also to be expected. The fact that the Assest-based Wealth indicator was highly significant, as was age, was not surprising; the elderly are more likely to be hungry in poor nations. These findings are consistent with the intrepretation that poverty is the primary cause of hunger in Benin.

This is not to say that there were some surpring findings in this paper, beginning with the importance of respondent perceptions about how well the government was handling whether people had enough to eat as well as raising the living standards of the poor. These results were contrary to earlier findings about respondent perceptions about the government and the HIV/ AIDS epidemic $[15,16]$ Simply, respondents who resided in countries with the high HIV/AIDS prevalence rates, including some with rising rates, indicated they thought their government was doing a good job handling the HIV/AIDS epidemic. By 
Table 4. Logistic regression with self-reported hunger as the dependent variable.

\begin{tabular}{|c|c|c|c|c|}
\hline Variable & Coefficient & Standard Error & $\mathbf{Z}$ & $\mathbf{P}$ \\
\hline Govt ensure people can eat & 0.92 & 0.14 & -6.38 & 0.000 \\
\hline Meeting basic needs & 0.55 & 0.09 & 6.21 & 0.000 \\
\hline Total assets & -0.23 & 0.07 & -3.44 & 0.00 \\
\hline Improve living standards & -0.53 & 0.16 & 3.40 & 0.00 \\
\hline Age & -0.25 & 0.09 & -2.69 & 0.01 \\
\hline Religion & -0.23 & 0.09 & -2.62 & 0.01 \\
\hline Agricultural worker & 0.54 & 0.24 & 2.26 & 0.02 \\
\hline Employment status & 0.13 & 0.09 & 1.46 & 0.15 \\
\hline Education & -0.07 & 0.08 & -0.85 & 0.39 \\
\hline Occupation & 0.11 & 0.12 & 0.96 & 0.34 \\
\hline Urban-rural & 0.07 & 0.13 & 0.56 & 0.58 \\
\hline Gender & -0.08 & 0.15 & -0.52 & 0.60 \\
\hline Number of observations & \multicolumn{4}{|c|}{1,009} \\
\hline LR chi2(12) & \multicolumn{4}{|c|}{187.73} \\
\hline Prob > chi2 & \multicolumn{4}{|c|}{0.0000} \\
\hline Pseudo R2 & \multicolumn{4}{|c|}{0.0000} \\
\hline
\end{tabular}

way of contrast, these Benin respondents indicated they thought the government was doing a poor job handling food insecurity and raising the living standards of the poor.

Another surprising finding was that gender did not predict the degree of hunger. When the female farmworkr issue was examed more closely roughly one quarter (26 percent) of those who listed their occupation as agriculure were female, and hunger was not found to be related to that breakdown (data not shown). Why religion, especially the food security status of Muslims. was so significant was not readily apparent. Age was less surprising in that the elderly are more likely to be hungry in poor nations.

The policy issue forthcoming from this study is that the government should develop and promote a public media campaign that stresses its recognition of hunger and discusses its current efforts to address hunger and the living standards of the poor. Regardless of the inability to have an impact, the government must acknowledge the problem and indicate it is doing all it can. If there is no funding available to address the hunger issue, the government should ackowledge that and indicate it is seeking external help to address hunger in Benin.

\section{Conclusion}

In conclusion, the answer to the question which generated this paper is that hunger will be or remain a continuing problem in Benin into the foreseeable future. Hidden hunger is apparent, with 71 percent of the respondents to this survey reporting some degree of hunger, and about one-fourth, 23 percent, reporting that they are hungry all the time. About 87 percent of the respondents in this study were unemployed and 59 percent listed some form of agriculture as their occupation. The surprising finding was that, while significant at the bivariate level, gender was not significant in the regression analysis, suggesting that everyone is hungry in Benin, women and men, and this study suggests there is no apparent improvement on the horizon. The policy implication of the study is that there is a need for the government to engage in a media campaign, indicating it is aware of the problem and addressing hunger to the best of its ability.

\section{References}

1. https://www.worldhunger.org/2015-world-hunger-andpoverty-facts-and-statistics/

2. Muthayya S, Jee H, Sugimoto J, et al. The global hidden hunger indices and maps: an advocacy tool for action. PLoS One. 2013;8:e67860.

3. http://www.fao.org/3/a-i4646e.pdf

4. Clover J. Food security in sub-saharan Africa: feature. African security review. 2003;12:5-15.

5. http://www.worldlifeexpectancy.com/burundi-lifeexpectancy

6. https://www.worldhunger.org/hunger-in-america-2016united-states-hunger-poverty-facts/

7. Sanchez P, Swaminathan M. Hunger in Africa: the link between unhealthy people and unhealthy soils. The Lancet. 2005;365:442-444.

8. Adebayo SA, Adekunle OA. Socio-economic status of women in group membership in selected areas of Kwara State, Nigeria. Agrosearch. 2016;16(1):57-64.

9. Fry JL. The value of publicly available data sets for social science research and evaluation. International Journal of Current Advanced Research. 2017;6(1):1777-83.

10. Bratton M, Mattes R, Boadi GE. Public opinion, democracy, and market reform in Africa. New York: Cambridge University Press. 2005.

11. Mattes R, Bratton M, Davids DY. Poverty, survival, and democracy in Southern Africa. Afrobarometer Working Paper No. 23. 2003.

12. Bratton M. Poor people and democratic citizenship in africa. Poverty, participation and democracy. New York: Cambridge University Press. .2010.

13. Long SJ, Freese J. Regression models for categorical dependent variables using Stata. USA: Stata Press. 2006. 
14. Fry JL. Is hunger destined to be perpetual in Burundi? Food Science and Nutrition Studies. 2017;1.

15. Fry JL. Continuities in the HIV/AIDS policy debate in South Africa. African Journal of Infectious Diseases. 2013;7:21-26.
16. Fry L. Assessing the HIV/AIDS MDGS: does this look like success or even progress? Pambazuka News. 2015.

\section{*Correspondence to:}

Lincoln J Fry

Sociology Research Unit

Athens Institute for Education and Research (ATINER)

Athens

Greece

Tel: 772-871-1709

E-mail: lincolnfry@bellsouth.net 